International Research Journal of Science and Technology Vol. 2, Issue. 2 (2021), 398-405

Available online at https://www.irjst.com/

International Research Journal of Science and Technology

ISSN: 2707-3955

DOI: https://doi.org/10.46378/irjst.2021.020205

\title{
Impacts of Urbanization on Seasonal Water Quality Dynamics in Mudi River in Blantyre District, Malawi
}

\author{
Sylvester Richard Chikabvumbwa ${ }^{1}$, Singanan Malairajan ${ }^{2 *}$, Sylvester William Chisale ${ }^{3}$ \\ ${ }^{1}$ University of Malawi, The Polytechnic, Private Bag 303, Chichiri, Blantyre 3, Malawi. \\ ${ }^{2}$ Presidency College (Autonomous), PG and Research Department of Chemistry, Chennai, Tamil Nadu. India. \\ ${ }^{3}$ Malawi University of Science and Technology, Box 5196, Limbe, Malawi.
}

\begin{tabular}{|c|c|c|}
\hline & Abstract \\
\hline \multicolumn{2}{|c|}{$\underline{\text { Paper Status }}$} & This study investigated the status of water quality in the Mudi River due to \\
\hline Received & Jan 2020 & urbanization and increasing soil erosion levels. Water samples were collected \\
\hline Accepted & Feb 2021 & strategic places i.e. before the city limit, within the city, and out-skirt the city. \\
\hline Published & Mar 2021 & $\begin{array}{l}\text { Physicochemical and biological parameters such as } \mathrm{pH} \text {, temperature, electric } \\
\text { conductivity (EC), total dissolved solids (TDS), and fecal coliforms were } \\
\text { examined on the Mudi River water. Obtained data were analyzed using Statistical } \\
\text { Package for Social Scientists and ArcGIS 10.8. The results revealed that the } \\
\text { Mudi River has lower water quality as most parameters exceeded the } \\
\text { recommended limits thresholds, which may found that the Mudi River water was }\end{array}$ \\
\hline \multicolumn{2}{|l|}{ Key Words } & polluted significantly. Even though, quality of the studied river water was found \\
\hline \multicolumn{2}{|c|}{ Mudi River } & as significantly better during the wet season than the dry season $(\mathrm{p}<0.05)$, which \\
\hline \multicolumn{2}{|c|}{ Public health } & may be due to the dilution effect of the rainfall. This study recommends to the \\
\hline \multirow{2}{*}{\multicolumn{2}{|c|}{$\begin{array}{l}\text { Sustainable management } \\
\text { Water quality }\end{array}$}} & concerned body to increase the environmental awareness, integrate the solid \\
\hline & & waste management in the city, proper drainage systems, rehabilitation of sewer \\
\hline \multicolumn{2}{|c|}{ Water pollution } & $\begin{array}{l}\text { lines, and creating a buffer to protect river bank cultivation and continuous } \\
\text { monitoring of the river using Geographic Information Systems. }\end{array}$ \\
\hline
\end{tabular}

Copyright (c) 2021: Sylvester Richard Chikabvumbwa, Singanan Malairajan, Sylvester William Chisale. This is an openaccess distribution, and reproduction in any medium, provided Access article distributed under the Creative Commons Attribution License the original work is properly cited License, which permits unrestricted use.

Citation: Sylvester Richard Chikabvumbwa, Singanan Malairajan, Sylvester William Chisale. "Impacts of Urbanization on Seasonal Water Quality Dynamics in Mudi River in Blantyre District, Malawi”, International Research Journal of Science and Technology, 2(2), 398-405, 2021.

\section{Introduction}

Even though sustainable development goal (SDG) 6 promotes access to clean and safe water, sustainable management of water, and sanitation for all, pollution of water sources is still a common problem in Africa. In developing countries like Malawi, pollution of water sources arises from human activities, entreated effluent from industries, insufficient untreated sewage, vehicular emissions, and agricultural fields [1].

\footnotetext{
* Corresponding author: Singanan Malairajan

Presidency College (Autonomous), PG and Research Department of Chemistry, Chennai, Tamil Nadu. India.

Email : mssinganan@yahoo.co.in
}

Poor water quality is detrimental to public health as it can result in diseases such as cholera and diarrhea [2]. Water quality monitoring for surface and subsurface sources is one of the planning strategies towards sustainable water resources management $[3,4]$. Water quality monitoring of rivers aids water managers to detect water quality problems in the rivers such as pollution, sedimentation and to identify proper solutions to such problems [5]. Understanding water quality variations in rivers [6] is therefore critical for decision making mainly if routine monitoring is not properly followed. This involves frequent collection and testing of water quality parameters (physical, biological, chemical) from the rivers at strategic 
points. The absence of data makes it difficult to identify degrees and trends of pollution in the river [7].

Considerable researches indicating the causes and importance of water quality monitoring and trend analysis in rivers has been conducted worldwide. Groppo et al. [8] asserted that water quality deteriorated in Brazil due to high population growth and increases in discharge of untreated wastewater into rivers. Uncontrolled effluent discharge from factories and domestic houses led to the declining levels of water quality in the Shiyang River was studied and reported by Ma et al. [9]. The study [10] indicated that high levels of some heavy metals in the rivers of Blantyre could be attributed to uncontrolled effluent discharge in rivers in Blantyre. Kannel et al. [11] monitored the water quality variations along the Bagmati River and found rising levels of nitrate and phosphorus, and attributed these to agricultural activities along the river. Kuyeli et al. [1] assessed the water quality levels in the rivers in Blantyre and concluded that the rivers were polluted especially in terms of biological oxygen demand due to poor waste management. In this context, in Malawi, lack of knowledge about pollution patterns as well as in the personal and infrastructural capacities to survey the water quality is still diverse calling for the need for surface water quality monitoring systems. The study was further extended and analyzed the water quality of Mudi River and attributed its declining levels due to industrial activities taking place in the city [1]. However, the findings did not evaluate the impact of land-use changes and soil erosion levels on the water quality in the rivers.

Many studies have explored the effect of urbanization on water quality. For instance, Ren et al. [12] observed that urbanization in Shanghai degraded the water quality of the Huangpu River. Chang (2005) highlighted that urbanization in Korea declined the water quality regimes of the Han River. In Nepal [11], urbanization increased the levels of phosphorus in the Bagmati River due to urbanization. Rostami, Merga et al. [13, 14] highlighted that hydro-meteorological variations have a considerable impact on the water quality in rivers. Using the Mudi River in Blantyre city as a case study, this research investigated the water quality changes in the river due to land changes and soil erosion levels from 1990 to 2018.

\section{Methodology}

\subsection{Study Area}

Figure 1 shows the location of the study area (Blantyre City), Limbe and Mudi rivers, and the sampling points where physical, biological and chemical water quality data was collected.

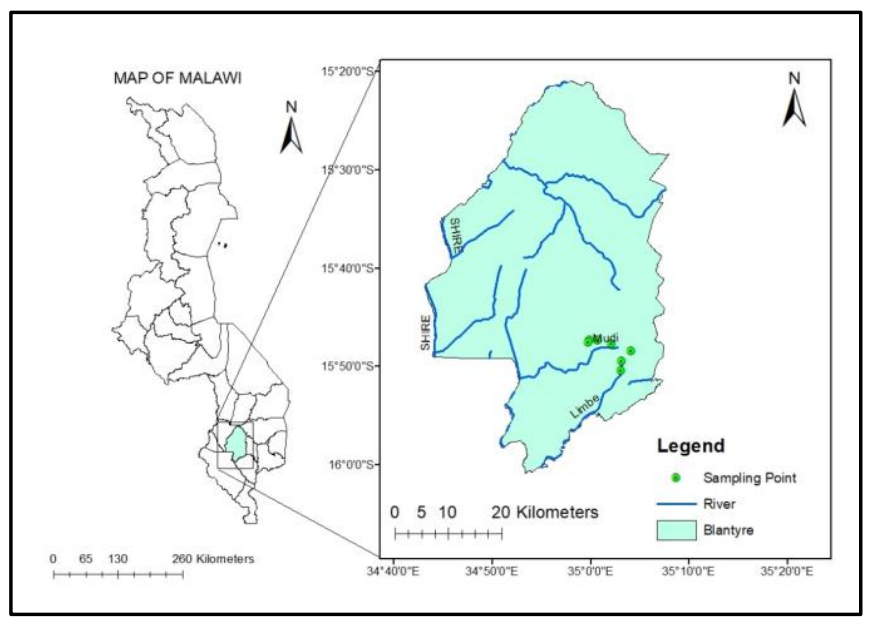

Figure 1. Blantyre City Map

\subsection{Data Collection}

Temperature and rainfall data for the past 30 years (1988-2018) was also collected from the Meteorological Department in Blantyre which was used to calculate the soil loss and determine erosion levels in the district. Soil loss was calculated using Gavrilovic's method which uses the equation:

$$
W=T H \pi Z^{1.5}
$$

where $=\left(0.1 T_{o}+0.1\right)^{0.5} ; \mathrm{W}$ is soil loss $\left(\mathrm{m}^{3} / \mathrm{km}^{2} / \mathrm{yr}\right)$; To is mean annual temperature $\left({ }^{\circ} \mathrm{C}\right) ; \mathrm{Z}$ is soil erosion coefficient; $H$ is mean annual soil precipitation; $\pi$ is 3.14. The coefficient $Z$ has been estimated from the FAO soil database. Gavrilovics $\mathrm{Z}$ defines erosion levels as follows: 0.1 for slight, 0.3 for slight to moderate, 0.5 for moderate, and 0.85 for moderate to severe.

Purposive sampling techniques were used to collect water samples from three sampling points (MSP1, MSP2, and MSP3) along the Mudi River. MSP1 was located before the city, MSP2 was within the city and MSP3 was after the city. The study was conducted in October 2019 (dry season) and January 2020 (rainy season). Water quality parameters such as $\mathrm{pH}$, electrical conductivity, total dissolved solids, turbidity, temperature, fecal coliforms, nitrates, sulfates, iron, $\mathrm{BOD}_{5}$, and phosphate were analyzed at the University of Malawi by procedures according to APHA [15].

\section{Results and Discussion}

The results for the physical and chemical parameters for the Mudi River were analyzed and compared with the standards of the World Health Organization (WHO) \& Malawi Bureau of Standards (MBS). Table 1 highlights the status of water quality parameters observed in dry season guidelines of WHO/MBS [16]. 
Table 1. Mean Levels of Different Water Quality Parameters in the Dry Season (October 2019)

\begin{tabular}{llllll}
\hline Water Quality Parameters & MSP1 & MSP2 & MSP3 & WHO & MBS \\
\hline $\mathrm{pH}$ & 8.5 & 8.3 & 7.7 & $6.6-8.5$ & $6.0-9.5$ \\
EC $(\mathrm{mS} / \mathrm{cm})$ & 155.0 & 328.0 & 568.0 & 400.0 & 400.0 \\
TDS $(\mathrm{mg} / \mathrm{l})$ & 153.0 & 560.0 & 518.0 & 1000.0 & 1000.0 \\
Turbidity $(\mathrm{NTU})$ & 12.6 & 16.5 & 1016.0 & 5.0 & 5.0 \\
Temperature $\left({ }^{\circ} \mathrm{C}\right)$ & 24.6 & 27.2 & 25.1 & - & - \\
FC $($ count/100ml) & 1320.0 & 3360.0 & 640.0 & 0.0 & 0.0 \\
Nitrates $(\mathrm{mg} / \mathrm{l})$ & 83.4 & 90.0 & 136.2 & 45.0 & 100.0 \\
Sulphate $(\mathrm{mg} / \mathrm{l})$ & 5.0 & 66.3 & 88.5 & 250.0 & 400 \\
Iron $(\mathrm{mg} / \mathrm{l})$ & 0.3 & 0.3 & 2.0 & 1.0 & - \\
BOD $(\mathrm{mg} / \mathrm{l})$ & 246.0 & 253.0 & 302.4 & 20 & 20.0 \\
Pholsphate $(\mathrm{mg} / \mathrm{l})$ & 1.6 & 3.5 & 5.6 & 0.5 & 0.5 \\
Lead $(\mathrm{mg} / \mathrm{l})$ & 0.6 & 0.9 & 0.8 & 0.05 & 0.05 \\
Chromium $(\mathrm{mg} / \mathrm{l})$ & 0.2 & 0.1 & 0.1 & 0.05 & 0.05 \\
Zinc $(\mathrm{mg} / \mathrm{l})$ & 0.1 & 0.2 & 0.2 & 15 & 15 \\
Copper(mg/l) & 0.05 & 0.14 & 0.09 & 1.5 & 2 \\
Calcium(mg/l) & 31.6 & 28.9 & 31.72 & 200 & 200 \\
\hline
\end{tabular}

Table 2, indicates the condition of water parameters in the Mudi River during the rainy

season, and how the relationship with the set thresholds of WHO and MBS.

Table 2. Mean Levels of Different Water Quality Parameters in the Wet Season (January, 2020)

\begin{tabular}{llllll}
\hline Water Quality Parameters & MSP1 & MSP2 & MSP3 & WHO & MBS \\
\hline $\mathrm{pH}$ & 7.6 & 7.4 & 7.2 & $6.6-8.5$ & $6.0-9.5$ \\
EC $(\mathrm{mS} / \mathrm{cm})$ & 134.0 & 213.0 & 307.3 & 400.0 & 400.0 \\
TDS $(\mathrm{mg} / \mathrm{l})$ & 153.0 & 560.0 & 518.0 & 1000.0 & 1000.0 \\
Turbidity $(\mathrm{NTU})$ & 12.6 & 16.5 & 1016.0 & 5.0 & 5.0 \\
Temperature $\left({ }^{\circ} \mathrm{C}\right)$ & 23.5 & 25.7 & 27.4 & - & - \\
FC/100ml & 940.0 & 1217.0 & 1040.0 & 0.0 & 0.0 \\
Nitrates $(\mathrm{mg} / \mathrm{l})$ & 83.4 & 90.0 & 136.2 & 45.0 & 100.0 \\
Sulphate $(\mathrm{mg} / \mathrm{l})$ & 4.6 & 44.3 & 71.1 & 250.0 & 400 \\
Iron $(\mathrm{mg} / \mathrm{l})$ & 0.2 & 0.3 & 2.0 & 1.0 & - \\
BOD $(\mathrm{mg} / \mathrm{l})$ & 102.8 & 153.1 & 199.3 & - & 20.0 \\
Pholsphate $(\mathrm{mg} / \mathrm{l})$ & 0.8 & 2.0 & 3.4 & 0.5 & - \\
Lead $(\mathrm{mg} / \mathrm{l})$ & 0.4 & 0.5 & 0.6 & 0.05 & 0.05 \\
Chromium $(\mathrm{mg} / \mathrm{l})$ & 0.2 & 0.1 & 0.1 & 0.05 & 0.05 \\
Zinc $(\mathrm{mg} / \mathrm{l})$ & 0.1 & 0.2 & 0.1 & 15 & 15 \\
Copper $(\mathrm{mg} / \mathrm{l})$ & 0.04 & 0.12 & 0.08 & 1.5 & 2 \\
Calcium $(\mathrm{mg} / \mathrm{l})$ & 22.6 & 26.7 & 30.1 & 200 & 200 \\
\hline
\end{tabular}

Table 1 and Table 2 indicate that the $\mathrm{pH}$ values in the dry and wet seasons were within the ideal $\mathrm{pH}$ requirement [17]. Even though there were reduced $\mathrm{pH}$ values in the river probably due to industrial effluents, there were no significant differences $(P>0.05)$ in the $\mathrm{pH}$ levels of the river in the dry and wet seasons. Temperature is an essential parameter as it is linked with the biochemical reactions that take effect in water bodies. Table 1 and Table 2 show that the temperature varied from 24.6 to $27.2^{\circ} \mathrm{C}$ in the dry season and ranged from 23.5 to $27.4{ }^{\circ} \mathrm{C}$ in the wet season respectively. 
Table 1 shows that the EC values in the river were above the recommended EC values for water suitable for irrigation or human consumption in the dry season. The EC values seemingly increased after passing through industrial areas (MSP2). These could be attributed to the effluent discharge from industries and wastewater leakages from sewer systems. However, EC values in the wet season as shown in Table 2 were lower than those in the dry season shown in Table 1. This could be due to the effect of dilution that came along with the rainfall.

The $\mathrm{BOD}_{5}$ values were extremely higher than the recommended values given by WHO and MBS in the river especially during the dry season. This could arise due to the mix-up of sewage from blocked sewer lines and solid waste which normally is dumped along the banks of the river. The high levels of $\mathrm{BOD}_{5}$ indicated deterioration of water quality in the river.

With regards to total dissolved solids and fecal coliforms, Mudi River exhibited very high levels of these parameters. Agricultural activities and domestic water uses such as washing and bathing that take place along the river could explain why these values were high in the river. Turbidity measures the cloudiness of water generally caused by clay, silt, and the presence of organic matter. The results indicated that water in the Mudi River was turbid with values above the baseline of 5 NTU. Mudi River also registered higher levels of nitrates especially in the dry season than the optimal requirements of nitrates in surface water. This could be attributed to the blocked sewer lines within the vicinity of the river and agricultural activities that take along the river banks. This finding supports the assertion of Kumar and Bahadur [18] that nitrate concentration in most water bodies is due to uncontrolled agricultural activities.

Similar to nitrate levels in the river, phosphate levels were extremely higher in the river. The levels increased tremendously downstream of the river after passing industrial areas. This suggested uncontrolled discharge of organic effluents such as phosphoric acids and phosphate detergents into the river. It is envisaged that agricultural activities that take place along the river also contribute to the high levels of phosphates as most farmers apply phosphate fertilizers in their farms and gardens. The metal load in the Mudi River was also high as indicated by the presence of high levels of lead, copper, chromium, zinc, and calcium. Apart from the incomplete industrial effluent discharge into the river, the increasing levels of metal concentration could also be attributed to agricultural fertilizers applied along the river. Traichaiyaporn and Chitmanat [19] asserted that fertilizers also increase the levels of heavy metals in water. The availability of heavy metals demonstrates that the river receives wastewater probably from sewage networks leakages and septic tanks. This agrees with the findings of Phiri et al., [20] whose study observed that the presence of heavy metals is due to leaking sewer systems.

Figure 2, exhibits the digital elevation model of the Blantyre district and its slopes.

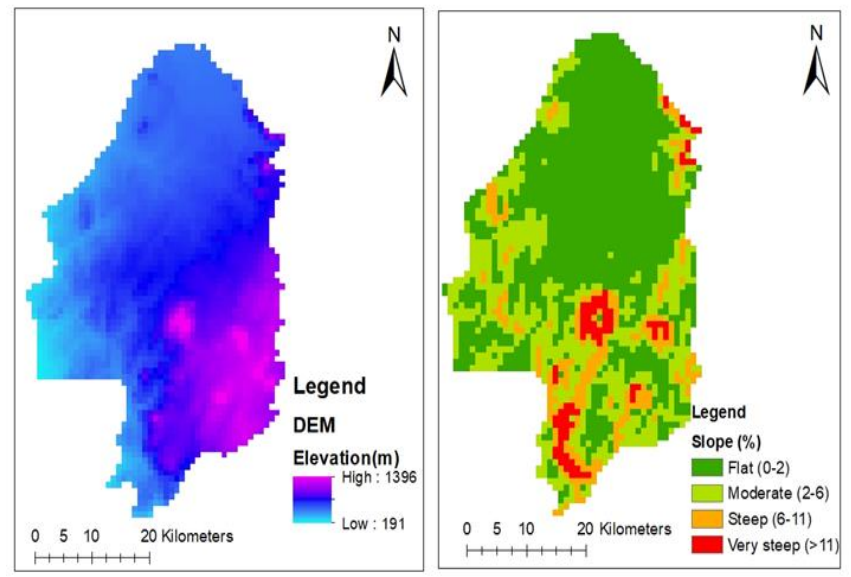

Figure 2. DEM and Slopes in Blantyre City

Figure 2 shows that the southeastern part of the district is on a higher elevation (1396 m) with prevalent steep (6-11\%) and moderate (2-6\%) slopes than the rest of the region. Mudi River flows from these mountains downstream through Blantyre commercial city which has a lot of industries. The steep slopes dominated with poor cultivation practices along the buffer zone of the river, and high deforestation rates in the mountains have contributed to the moderate erosion levels in the catchment area as shown in Figure 4. This agrees with the findings of Kidane and Adamu [21] that observed that deforestation and hastens water erosion resulting in land degradation upstream of a catchment and water quality degradation in down streams. Figure 3 below shows the land uses in the Blantyre district.

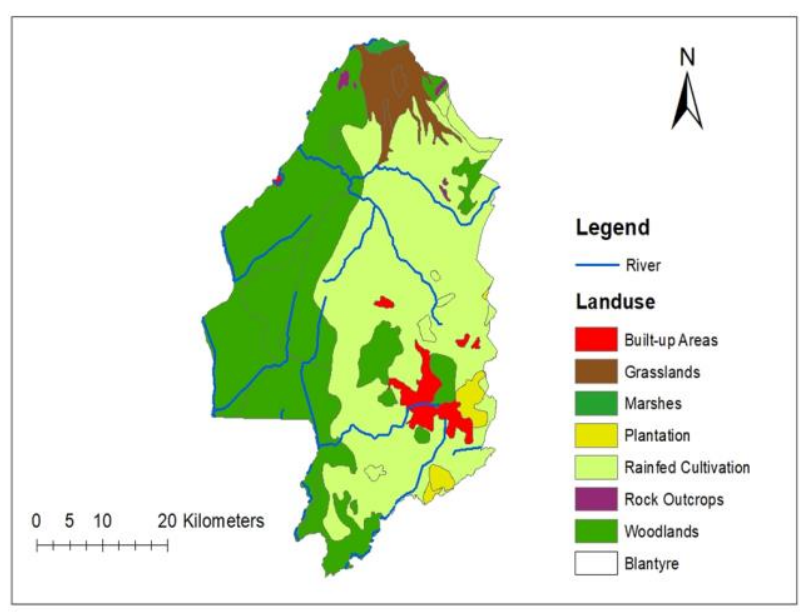

Figure 3. Land uses in Blantyre 
Figure 4 depicts the soil erosion levels in the Blantyre district. Soil erosion is pervasive predominantly on the steep slopes. Figure 3 shows that the Mudi River passes through Blantyre city which is increasing in urbanization rates and population. The increasing level of urbanization as seen in Figure 3 correlates with the high erosion levels seen in Figure 4. This finding concurs with the results of Mawenda et al., [22] that observed that there has been an increase in built-up area from $4.1 \%$ to $7 \%$ which has led to the loss of vegetation. It is this loss of vegetation that leads to the declining of ecological balances such as water quality and flood mitigation.

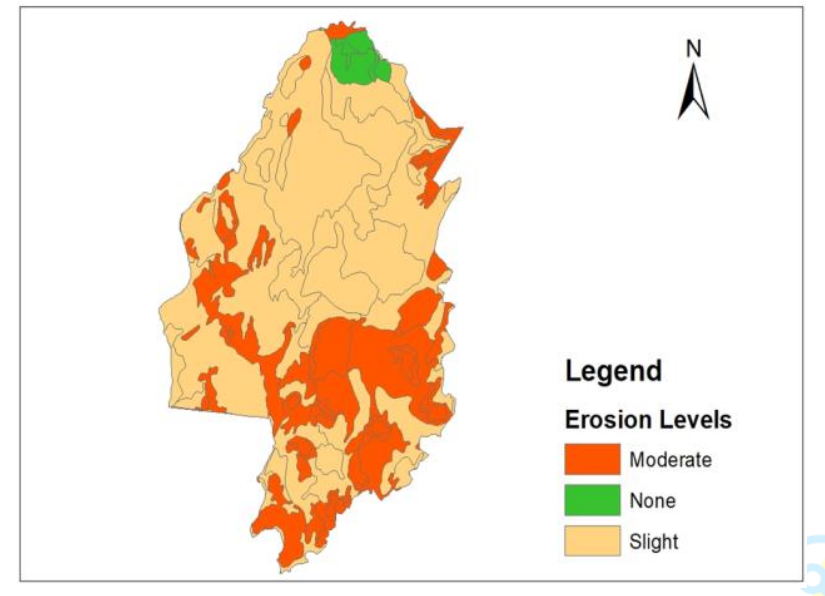

Figure 4. Erosion Levels in Blantyre City

The results further indicated that with an average of $1086 \mathrm{~mm}$ of rainfall and $20.7^{\circ} \mathrm{C}$ of temperature, the Blantyre district has a medium annual soil loss of $825.4 \mathrm{~m}^{3} / \mathrm{km}^{2} / \mathrm{yr}$ and the slight annual loss of 158.9 $\mathrm{m}^{3} / \mathrm{km}^{2} / \mathrm{yr}$. Chichiri area which has a network of most rivers understudy has a moderate annual soil loss of $807.6 \mathrm{~m}^{3} / \mathrm{km}^{2} / \mathrm{yr}$ and a slight annual soil loss of 155.4 $\mathrm{m}^{3} / \mathrm{km}^{2} / \mathrm{yr}$ whilst Chileka has a moderate annual soil loss of $710.9 \mathrm{~m}^{3} / \mathrm{km}^{2} / \mathrm{yr}$ and slight annual soil loss of $136.8 \mathrm{~m}^{3} / \mathrm{km}^{2} / \mathrm{yr}$.

Figure 5 displays the changes in land use patterns in the Blantyre district from 1990 to 2010.

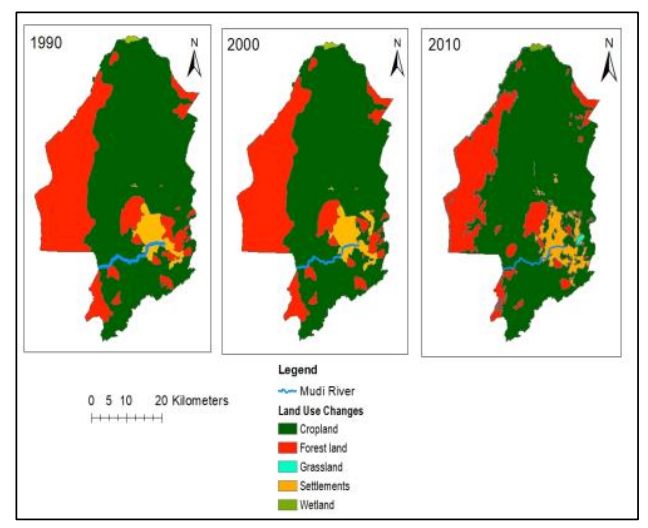

Figure 5. Land Use Changes in Blantyre City

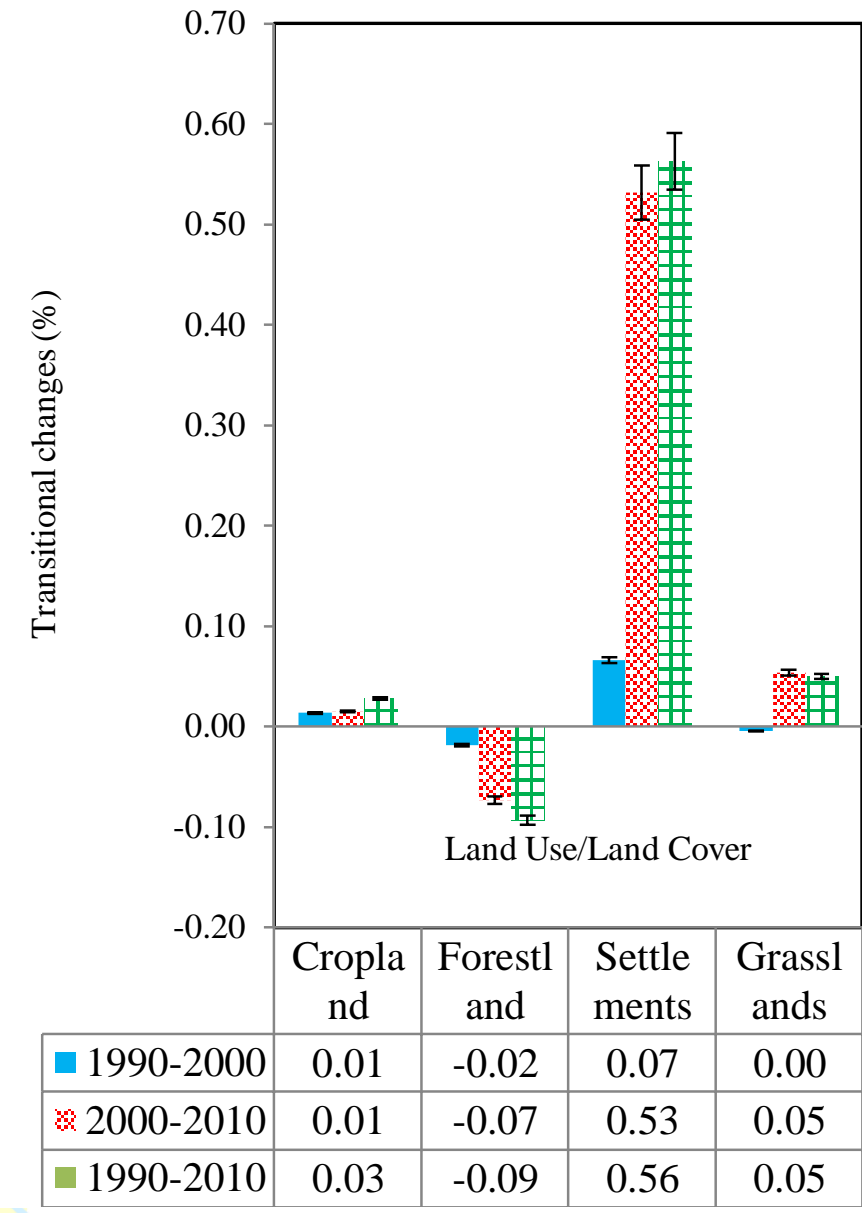

Figure 6. Transitional changes in Land Use/Land cover in Blantyre district

Figure 6 indicated that there was an increase in cropland in the Blantyre district by $3 \%$, a decrease in forest land by $9 \%$ and an increase in settlement by $56 \%$, and an increase in grassland by 5\% from 1990 to 2010. These changes could be due to an increase in population and urbanization in the city as seen in Figure 5 above. These changes specifically an increase in settlements, an increase in built-up land, and the decrease in forest land suggested a decrease in vegetation cover. These activities have numerous effects on the surface water quality of rivers in the district.

Figure 7 presents the changes in land use patterns in Blantyre city where the river passes through from 1994 to 2018. In the present study of the Mudi River located in the urban Blantyre city, urbanization, deforestation, and soil erosion have contributed to the pollution of the river. The sharp increase in urbanization combined with the high levels of erosion in the city correlates significantly with the deterioration of the water quality levels in the Mudi River. This concurs with the findings of Pires et al., [23] that asserted that urbanization increases sewage discharge into the rivers leading to an imbalance in water quality parameters. 

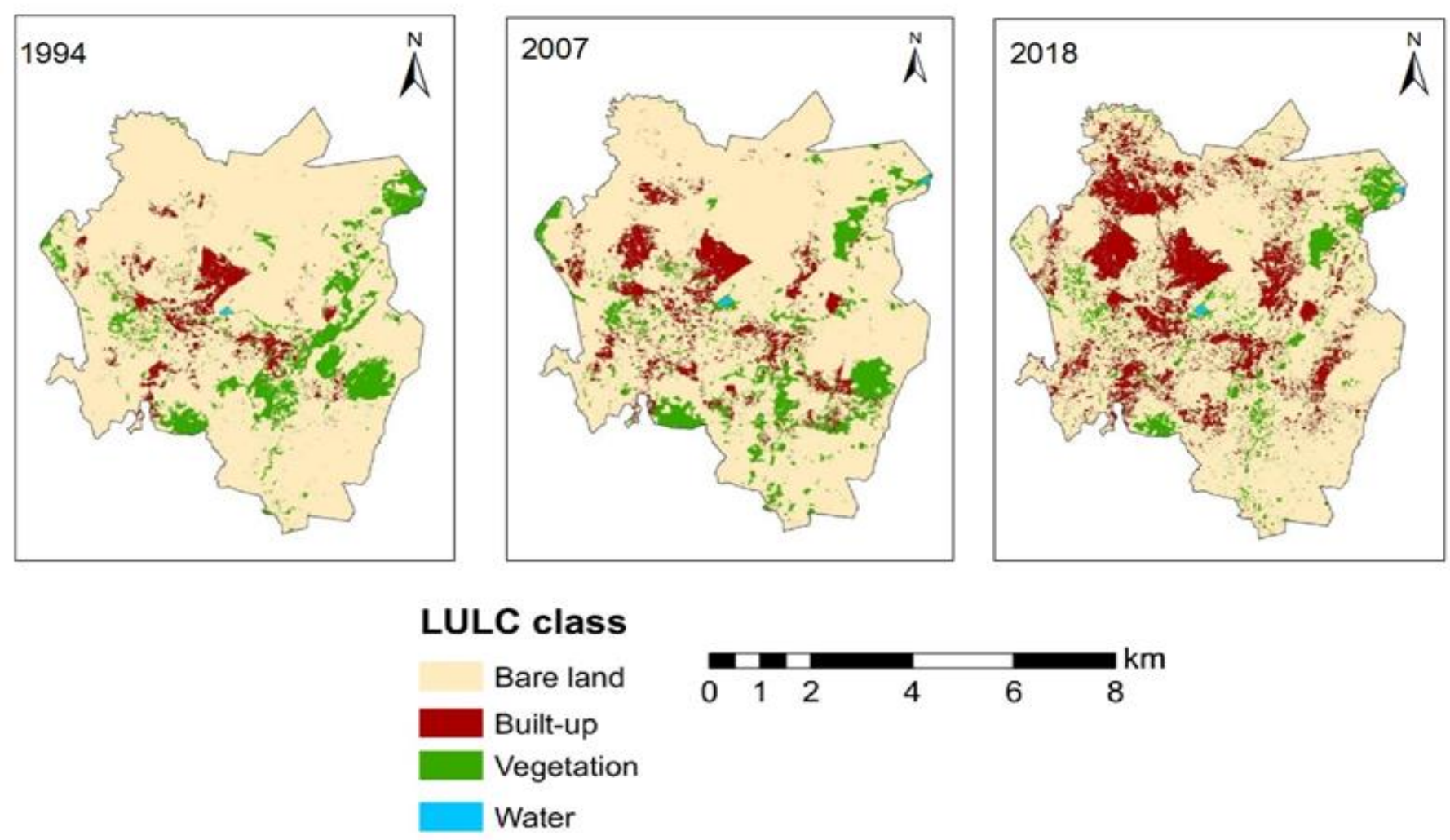

Figure 7. Changes in land-use patterns in Blantyre city

The current findings suggest further deterioration of the Mudi River due to high erosion levels upstream of the catchment that is contributing to sediment overload in the river thereby reducing its water quality. The results also indicate increasing urbanization and population growth that is further degrading the quality of water in the river. The independent t-test at $99 \%$ confidence interval highlighted that the mean levels of most water quality parameters are extremely and significantly higher in the dry season than the rainy season $(p<0.001)$ considerably due to the rains that have a dilution effect.

Figure 8 highlights the cause diagram of water quality changes in the Mudi River. It traced some of the causes of pollutant load variations in the Mudi River. All the study (Figure 8) revealed that the river is polluted due to anthropogenic activities taking place along the river. Specifically, there are high rates of deforestation upstream of the river that leads to soil erosion which results in the decline of water quality. The study further indicates that other pollutants emerge from effluents from factories and industries, blocked sewer lines and septic tanks, poor drainage systems, agricultural activities, poor disposal of wastes from the Blantyre market, and effluent from inefficient wastewater treatment plants.

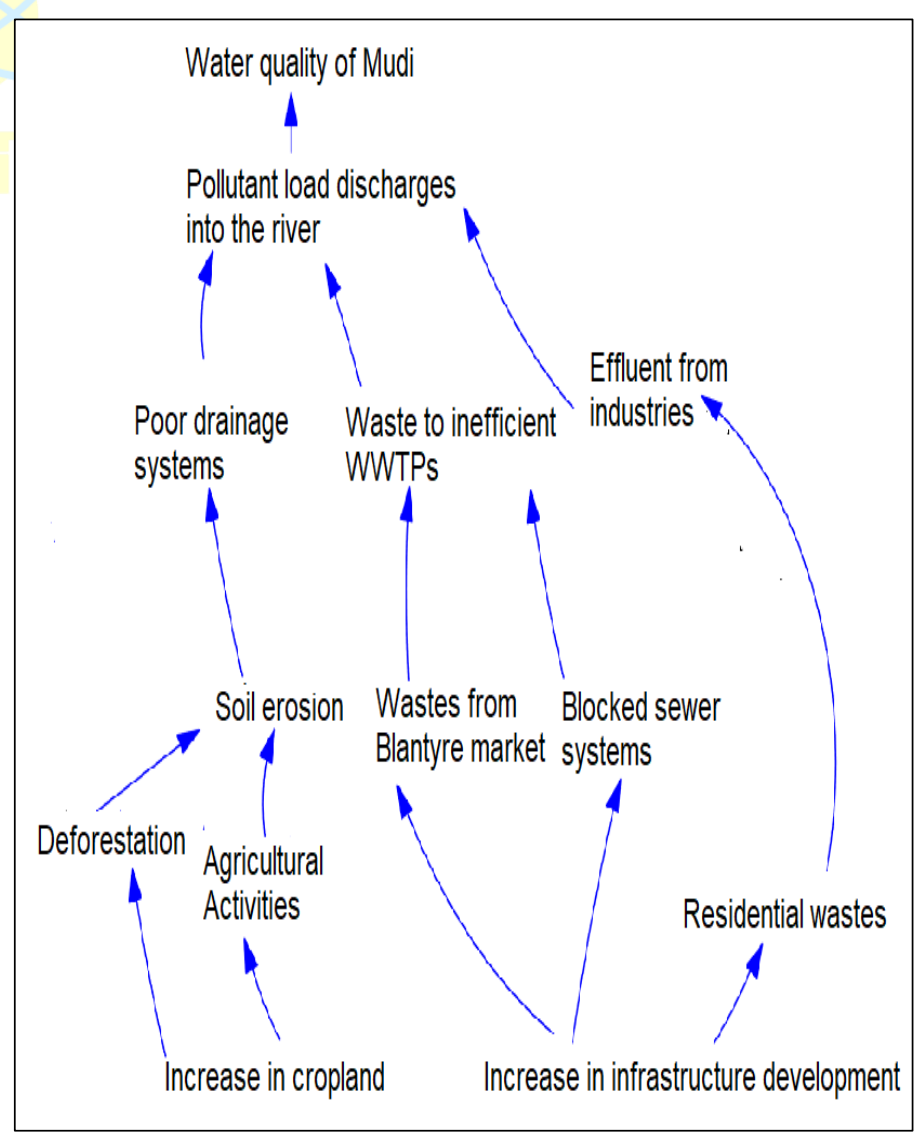

Figure 8 . Cause diagram of water quality changes in Mudi River 
The findings of this study concur with the study of $\mathrm{Su}$ and Qin [23] that reported that water quality is better in the wet season than in the dry season. This study further observed that pollutant discharge in Mudi River is a function of the difference between the total pollutant load generated within Mudi River and the pollutant load removed by wastewater infrastructure within the city. Mathematically, it would be presented as $[25,26]$ :

$$
\mathrm{P}_{\mathrm{q}}=\mathrm{P}_{\mathrm{t}}-\mathrm{P}_{\mathrm{w}}
$$

Where $\mathrm{P}_{\mathrm{q}}$ is the pollutant total discharge into Mudi river, $\mathrm{Pt}$ is the total pollutant load generated within Mudi River and $\mathrm{Pw}$ is the pollutant load removed by wastewater infrastructure within Blantyre city.

\section{Conclusions}

This study investigated the effect of soil erosion and urbanization on the water quality levels in the Mudi River. The results indicate that the Mudi River is highly polluted due to agricultural activities taking place along the river banks. These agricultural activities further enhance soil erosion contributing to the deposition of chemicals in the river. The study further indicates that industrial discharges and blocked sewer lines in the area are reducing the quality of surface water in the river. The study also shows that there are high levels of deforestation along the river bank due to an increasing level of urbanization in the city. This increases the levels of erosion in the city.

The high level of deterioration of the waters of the Mudi river call for the proper management of solid and liquid wastes from communities and industries to reduce the deposition of wastes into the river. This study further recommends integrated solid waste management in the city, proper drainage systems, rehabilitation of sewer lines, and creating a buffer to protect river bank cultivation. This study concurs with earlier studies that suitable for water management measures such as increasing capacities and/or rehabilitating wastewater treatment plants, maintaining urban drainage systems, river basin management should always be included in the urbanization process to mitigate and reduce the dropping levels of water quality in rivers.

This study further recommends that the increased environmental awareness and the continuous monitoring of the river using Geographic information systems to determine its status and the status of the river downstream river water.

\section{Acknowledgments}

The authors acknowledge Chikondi Laisani for collecting data and measuring the water parameters at Polytechnic Laboratory.

\section{Conflict of Interest}

The authors declare no conflict of interest.

\section{Author Contributions}

Sylvester Richard Chikabvumbwa developed, analyzed the data, and prepared the manuscript. Singanan Malairajan aided in analysis and interpretation. Sylvester William Chisale assisted in data analysis and manuscript preparation. All authors have read, agreed, and approved the final manuscript.

\section{References}

[1]. S.M. Kuyeli, W.R.L. Masamba, E. Fabiano, S.M. Sajidu, E.M.T. Henry. Temporal and spatial physicochemical water quality in Blantyre urban streams. Malawi J. Sci. Technol. 2009; 9(1), 5-10.

[2]. Z.P. Ndlela, B.R.T. Vilane and N.F. Nkambule. An assessment of the Mvutjini earth dam water quality at Kalanga, Swaziland. J. Agric. Sci. Eng. 2017; 3(1), 13-19.

[3]. A.L.T. Souza, D.G. Fonseca, R.A. Libório and M.O. Tanaka. Influence of riparian vegetation and forest structure on the water quality of rural loworder streams in SE Brazil. For. Ecol. Manage. 2013; 298, 12-18.

[4]. H. Qin, Q. Su, S. Khu, and N. Tang. Water quality changes during rapid urbanization in the Shenzhen River catchment: An integrated view of socioeconomic and infrastructure development. Sustainability. 2014, 6, 7433-7451.

DOI: $10.3390 / \mathrm{su} 6107433$.

[5]. V.Antonopoulos, D. Papamichail and K. Mitsiou. Statistical and trend analysis of water quality and quantity data for the Strymon river in Greece. Hyd. Earth Sys. Sci. 2001; 5(4), 679-691.

[6]. H.P. Qin, Q. Su and S.T. Khu. An integrated model for water management in a rapidly urbanizing catchment. Environ. Model. Softw. 2011; 26, 1502-1514.

[7]. F.M. Hassan, M.M. Saleh and J.M.A. Salman. Study of physicochemical parameters and nine heavy metals in the Euphrates River, Iraq. E-J. Chem. 2010; 7(3), 685-692.

[8]. J.D. Groppo, J.M. de Moraes, C.E. Beduschi, A.M. Genovez, and L.A. Martinelli. Trend analysis of water quality in some rivers with different degrees of development within the São Paulo State, Brazil. River Res. Appl. 2008; 24, 1056-1067. 
[9]. J.Z.Ma, ZY Ding, G.X. Wei, H. Zhao and T.M. Huang. Sources of water pollution and evolution of water quality in the Wuwei basin of Shiyang river, Northwest China. J. Environ. Manage. 2009; 90, 1168-1177.

[10]. S.M.I. Sajid, E.M.T. Henry, W.R.L. Masamba and S.M. Kuyeli. Wastewater quality inventory compilation and distribution of heavy metals in streams and wastewater plants of Blantyre, Malawi, 7th WATERnet/WARFSA Symposium, 2006, Lilongwe, Malawi, November 2006.

[11]. P.R. Kannel, S. Lee, S.R. Kanel, S.P. Khan, and Y.S. Lee. Spatial-temporal variation and comparative assessment of water qualities of urban river system: A case study of the River Bagmati (Nepal). Environ. Monitor. Assess. 2007; $129,433-459$.

[12]. W.W. Ren, Y. Zhong, J. Meligrana, B. Anderson, W.E. Watt, J.K. Chen and H.L. Leung. Urbanization, land use, and water quality in Shanghai 1947-1996. Environ. Int. 2003; 29, 649 -659 .

[13]. S.Rostami. Water-quality response to hydrometeorological variation in Alberta Rivers (Unpublished master's thesis). University of Calgary, Calgary, AB. 2017. https://doi.org/10.11575/PRISM/28674.

[14]. H. Merga, Y. Belete, and D. Ramesh. Seasonal Influence on quality of water collected from Chamo lake, Arba Minch, Ethiopia. Water and Energy International. 2018: 61r (8), 47-56.

[15]. American Public Health Association (APHA). Standard methods for examination of water and wastewater, $20^{\text {th }}$ ed, Washington, DC, USA, 1998.

[16]. Malawi Bureau of Standards (MBS). Drinking water-specification, 1st revision, MS 214: 2005.

[17]. WHO. Guidelines for drinking water quality $4^{\text {th }}$ ed. 2011; http://www.who.int.

[18]. A.Kumar and Y.Bahadur. Physicochemical studies on the pollution potential of river Kosi at Rampur. World J. Agric. Sci. 2009: 5(1), 1-4.

[19]. S.Traichaiyaporn and C.Chitmana. Water quality monitoring in upper Ping River, Thailand. $J$. Agric. Soc. Sci. 2008; 4, 31-34.

[20]. O.Phiri, P.Mumba, B.H.Z.Moyo and W. Kadewa. Assessment of the impact of industrial effluents on water quality of receiving rivers in urban areas of Malawi. Int. J. Environ. Sci. Technol. 2005; 2, 237-244. https://doi.org/10.1007/BF03325882.
[21]. D. Kidane and B. Alemu. The effect of upstream land-use practices on soil erosion and sedimentation in the upper Blue Nile basin, Ethiopia. Res. J. Agric. Environ. Manage. 2015; 4 (2), 055-068.

[22]. J. Mawenda, T. Watanabe, and R. Avtar. An Analysis of Urban Land Use/Land Cover Changes in Blantyre City, Southern Malawi (1994-2018). Sustainability. 2020, 12(6),2377. https://doi.org/10.3390/su12062377.

[23]. N.L. Pires, D. Heloisa, D.F. Muniz and T.B. Kisaka. Impacts of the urbanization process on water quality of Brazilian Savanna rivers: The case of Preto river in Formosa, Goiás state, Brazil.2015;10671-10686. https://doi.org/10.3390/ijerph120910671.

[24]. Q. Su and H.P. Qin. Environmental and ecological impacts of water supplement schemes in a heavily polluted estuary. Sci. Total Environ. 2014; 472, 704-711.

[25]. J.D. Duh, V. Shandas, H. Chang and L.A. George. Rates of urbanization and the resiliency of air and water quality. Sci. Total Environ. 2008; 400, 238-256.

[26]. R.C. Ferrier, A.C. Edwards, D. Hirst, I.G. Little wood, C.D. Watts and R. Morris. Water quality of Scottish rivers: Spatial and temporal trends. Sci. Total Environ. 2001; 265, 327-342. 